\title{
Memaknai Iconography Kristen dari Perspektif Keluaran 20:4-6
}

\author{
James A. Lola \\ Sekolah Tinggi Agama Kristen Negeri Toraja \\ jnlola86@gmail.com
}

\begin{abstract}
The presence of statues in the Church has led a debate in various aspects of life, one of the issues raised is related to the commandments in God's ten commandments not to make statues and to worship the statue (Exodus 20: 4-6, ; Deut. 5 : 8-10; Im. 19: 4). As much as possible, this study wants to see how this statue relates to the second commandment of ten laws. In the hermenutic approach, the researcher found that the meaning of this command was to clearly reject the establishment of a statue that was used to personalize divinity especially believed to be a manifestation of God himself.
\end{abstract}

Keywords: Excodus 20; statue; the Law

Abstraksi: Kehadiran patung dalam Gereja telah menimbulkan pro dan kontra dalam berbagai aspek kehidupan, salah satu isu yang dimunculkan adalah berkaitan dengan salah satu perintah dalam sepuluh perintah Allah untuk tidak membuat patung dan sujud menyembah patung tersebut (Keluaran 20:4-6, bandingkan Ul. 5:8-10; Im.19:4). Penelitian ini sedapat mungkin ingin melihat bagaimana hubungan patung ini dengan perintah kedua dari sepuluh hukum. Dalam pendekatan hermenutik, peneliti menemukan bahwa makna dari perintah ini adalah dengan jelas menolak pendirian patung yang digunakan untuk mempersonafikasikan keillahian apalagi dipercaya sebagai wujud dari Allah itu sendiri

Kata Kunci: Keluaran 20; Hukum Taurat; patung

$\begin{array}{llll}\text { Article History: } & \text { Received: 14-12-2018 } & \text { Revised: 24-12-2018 } & \text { Accepted: 27-12-2018 }\end{array}$

\section{Pendahuluan}

Seperti yang akan dikemukakan berikut ini, fokus riset ini adalah pada Keluaran 20:4-6 (band. Ul. 5:8-10; Im.19:4) yang berkaitan dengan salah satu perintah Tuhan kepada umat Israel untuk tidak membuat patung dalam bentuk apapun. Ketertarikan untuk melakukan riset ini didasarkan kepada pengalaman ketika mencermati fenomena patung (Yesus) yang ada di Burake, Tana Toraja, di mana dalam pengamatan penulis patung (Yesus) Burake telah menjadi sebuah ikon bagi kota Toraja untuk mencirikan bahwa kabupaten Toraja adalah kabupaten yang mayoritas penduduknya beragama Kristen dan juga bahwa patung itu telah dijadikannya sebagai wisata rohani (religi). 
Sebenarnya ada begitu banyak polemik yang terjadi dalam proses pembangunan patung tersebut, polemik-polemik tersebut banyak yang berkaitan dengan politik, sosial dan juga polemik yang berkaitan dengan pro dan kontra dari gereja berkaitan dengan kehadiran patung tersebut. Kebanyakan pro dan kontra di dalam Gereja itu disebabkan pada pemahaman akan perintah dalam sepuluh perintah Allah yang dicatat dalam Keluaran 20:4-6 dan Imamat 19:4 mengenai larangan untuk membuat patung tersebut. Kebanyakan dari pihak (gereja) yang menentang pendirian patung ini mendasarkan pemahaman pada pemaknaan literer dari teks ini bahwa pendirian patung adalah pelanggaran terhadap perintah kedua (2) dari sepuluh perintah Allah dan bahwa perintah ini masih harus ditaati oleh orang percaya pada masa kini, sehingga pembuatan patung adalah tidak dibenarkan.

Sebenarnya persoalan mengenai pembuatan patung bukanlah sebuah persoalan yang semata-mata hanya menjadi pergumulan dari masyarakat dalam lingkup Gereja Toraja melainkan persoalan ini telah menjadi sebuah persoalan yang cukup panjang di sepanjang sejarah gereja berkaitan dengan boleh atau tidak orang Kristen membuat gambar dan atau patung Yesus. Sejarah mencatat bahwa gereja sering bergumul dengan hal ini, karena terdapat indikasi yang cukup kuat bahwa patung (gambar) selalu identik dengan penyembahan berhala sehingga sering yang terjadi adalah penolakan bahkan penghancuran terhadap patung-patung, misalnya pada tahun 725 M sebuah peristiwa yang dikenal dengan peristiwa Byzantium, yaitu ketika Kaisar Leo III memerintahkan penghancuran semua imaji gerejawi dan melakukan kekerasan atas mereka yang menyukai patung-patung. ${ }^{1}$

Gereja tidak selalu bersifat destruktif terhadap patung-patung sebagai simbol keagamaan, karena ada periode di mana justru gereja menjadikan patung-patung sebagai simbol-simbol yang bersifat sakral dan memiliki nilai religius, dan periode itu berlangsung pada kurun waktu yang cukup panjang bagi gereja. Asumsi utama dari Gereja ketika menerima penggunaan patung-patung sebagai simbol keagamaan adalah, bahwa patung dan seni rupa lainnya yang ada di dalam gereja merupakan sarana edukasi yang mengajarkan tentang kebesaran Allah yang terlihat dalam segala ciptaan terutama bagi anggota jemaat yang buta huruf ${ }^{2}$, dan juga mengacu kepada Perjanjian Lama sendiri yang memuat begitu banyak simbol yang melambangkan realitas spiritual.

Namun, tidak dapat dipungkiri bahwa tindakan penghancuran dan kekerasan ini justru kemudian memuncak pada masa reformasi, ketika para reformator mencoba untuk mengidentifikasikan tindakan penghancuran akan patung-patung menjadi simbol

1 Genevieve Young, "Byzantine Iconoclasm: An Imperial Religious Policy Aimed at Unification?" dalam Phronema 23 (2008), 35-49.

${ }^{2}$ Bagi beberapa pihak, patung dan seni rupa lainnya yang ada di dalam Gereja memiliki fungsi yang sama dengan Firman, menurut mereka jika Firman memberikan kesaksian melalui pendengaran maka patung dan seni rupa lainnya memberikan kesaksian melalui penglihatan mata. 
dari reformasi itu sendiri untuk membedakan gereja yang sudah direformasi dan Gereja Katolik Roma yang memiliki tradisi yang kuat berkaitan dengan pembuatan patungpatung. ${ }^{3}$

Meskipun hal ini tidak selamanya dibenarkan karena justru fakta memperlihatkan bahwa pengaruh penggunaan patung-patung dalam simbol keagamaan tidak sepenuhnya lepas dari kekristenan reformasi. Hal ini diutarakan oleh Willem Van Assel sebagaimana dirangkumkan oleh Joas Adiprasetya dalam makalahnya

Willem van Assel menyimpulkan bahwa terdapat sebuah serat yang mempersatukan mereka, yaitu bahwa kaum reformasi melakukan "sejenis dekonstruksi atas masa silam teologis dan religiusnya sendiri." Dengan perkataan lain, ikonoklasme Protestan merupakan sebuah usaha meneguhkan identitas baru yang berbeda dari gereja lama mereka, yang direpresentasi melalui ikon dan imaji religius. Lebih lanjut, van Assel menolak sebuah komparasi yang menurutnya terlalu distorsif, yang menyatakan bahwa spiritualitas Protestan lebih verbal dan aural, sedangkan spiritualitas Katolik lebih visual. Menurutnya, spiritualitas Abad Pertengahan juga menekankan dimensi mendengar dan membaca, sedang spiritualitas reformasi memberi penekanan cukup besar pada dimensi visual. Bahkan, dengan ditemukannya mesin cetak, Protestantisme melahirkan pula budaya popular yang berbasis pada seni visual. Van Assel akhirnya menyimpulkan bahwa wajah Protestantisme sebagai iconoclast (image-breaker) secara perlahan berubah menjadi image-maker. Dengan demikian, apa yang berlangsung kemudian adalah pertarungan dua sistem ikonik dari dua kelompok religius (iconoclash). 4

Sekali lagi yang menjadi landasan dari tindakan tersebut adalah Keluaran 20:4-6. Yang adalah teks yang menjadi fokus riset kali ini dan juga beberapa teks yang secara khusus melarang orang Israel untuk mendirikan patung, karena penggunaan patung dalam konteks keagamaan disinyalir dapat menggiring umat pada praktik penyembahan berhala secara tidak langsung. Dan juga alasan di balik penolakan ini didasarkan pada pemahaman mengenai Kristus, bahwa penggunaan patung seakan-akan hanya melambangkan tentang kemanusiaan Yesus semata dan melepaskan keilahian-Nya, serta bahwa penggambaran Yesus dalam bentuk patung adalah tidak sesuai dengan penjelasan Yesus sendiri, karena Yesus justru memberikan gambaran akan dirinya dalam bentuk metafora roti dan anggur bukan pada patung.

Perdebatan-perdebatan yang terjadi mengenai tafsir terhadap hukum kedua dari sepuluh larangan ini sampai saat ini masih menjadi salah satu isu yang penting dalam kekristenan yang menurut hemat penulis perlu untuk diteliti lebih jauh terutama berkaitan dengan apakah diperbolehkan membuat patung Yesus, dan juga berkaitan dengan bagaimanakah kekristenan melihat pembuatan patung Yesus serta bagaimana

${ }^{3}$ Sampai saat ini Gereja Katolik masih memberikan ruang yang cukup besar pada penggunaan simbol-simbol keagamaan melalui patung dan karya seni lainnya. Bahkan penggunaan 'image' pada permulaan reformasi merupakan salah satu isu utama yang dijadikan sebagai bahan utama kontroversi dengan para reformator 2014

${ }^{4}$ Joas Adiprasetya, Makalah Ikonografi Protestan Diskusi Panel Ikonografi di LAI, Jakarta, 24 April 
menilai penggunaan patung burake sebagai tempat yang dijadikan sebagai wisata religi di Tana Toraja.

\section{Metode Penelitian}

Penelitian ini sedapat mungkin akan mencoba mengelaborasi poin-poin diatas dari sudut pandang Alkitab terutama berkaitan dengan perintah kedua dari sepuluh hukum yang ada pada Keluaran 20:4-6. Pendekatan yang digunakan dalam melakukan riset ini adalah dengan mencoba mendekatinya secara hermeneutis yang mengacu pada pendekatan historis gramatical, yang dimaksud di sini adalah mencoba mendekati dari sudut historis berkaitan dengan bagaimana pengimplementasian dari teks Keluaran 20:4-6 dan teks-teks lainnya yang berkaitan dengan isu ini di dalam sejarah kekristenan, dan juga mengacu kepada elaborasi gramatical teks keluaran 20:4-6 untuk menemukan makna (tafsir) dari bagian ini dalam konteks gereja di masa kini.

Pendekatan yang pertama diperlukan untuk melihat bagaimana para bapak-bapak Gereja memaknai teks tersebut dalam zamannya mereka untuk dijadikan sebagai perbandingan terhadap konteks Burake pada masa kini, sedangkan pendekatan kedua lebih diarahkan pada tafsir untuk mengetahui maksud asli dari perintah kedua dari sepuluh hukum ini diberikan, dan melalui pendekatan ini dapat ditarik maknanya untuk menganalisa fenomena patung (Yesus) Burake di Tana Toraja.

\section{Landasan Konsep Hermeneutik Kitab Keluaran}

Gordon Fee dalam bukunya menyatakan bahwa tugas pertama dari seorang penafsir Alkitab adalah melakukan eksegese. Eksegese adalah hal mempelajari Alkitab secara sistematis dan teliti untuk menemukan arti asli yang dimaksudkan. Pada dasarnya hal ini adalah suatu tugas yang berkenaan dengan sejarah, suatu usaha untuk mendengar Firman sebagaimana penerima yang mula-mula. ${ }^{5}$ Dalam hal ini, proses penafsiran lebih bersifat 'interpretasi gramatis' yaitu memahami sebuah teks bertolak dari bahasa dan struktur kalimat-kalimat dan hubungan teks tersebut dengan teks-teks lain dengan jenis yang sama. Upaya ini lebih mendekati pada pola hermeneutik reproduktif dari Schleiermacher yaitu berusaha menghadirkan seutuhnya maksud sesungguhnya dari penulis teks tersebut. ${ }^{6}$

Studi eksegesis ini dilakukan dalam dua bentuk yaitu induktif dan deduktif. Studi induktif yang dimaksud adalah berinteraksi dengan teks secara langsung untuk membentuk kesimpulan, sedangkan studi deduktif adalah interaksi dengan kesimpulan

\footnotetext{
${ }^{5}$ Gordon D. Fee dan Douglas Stuart, Hermeneutik: Bagaimana Menafsirkan Firman Tuhan dengan Tepat! (Malang: Gandum Mas, 2006), 19

${ }^{6}$ Masalah utama dari pendekatan ini adalah apakah ada kemungkinan menemukan makna asli dari suatu teks? Meskipun para penulis asli hanya mempunyai satu makna, namun sekarang makna tersebut sudah tida ada lagi karena penulis tersebut tidak hadir untuk memastikan dan menjelaskan apa yang mereka tulis. Bagi para pembaca modern pasca Scheleiermacher penafsiran yang objektif itu tidaklah mungkin dilakukan dan makna yang dimaksud penulis telah hilang selamanya. Makna tersebut selalu berbeda di setiap komunitas jadi kenyataannya teks selalu memiliki beragam makna.
} 
dari para sarjana dengan mengerjakan penemuan-penemuan yang telah dibuat. Dalam uraiannya tentang Genre Taurat, Osborne menjelaskan bahwa pembacaan terhadap kitab Taurat harus dimulai dengan mengerti dan memahami penggunaan Taurat itu dalam Perjanjian Lama. Istilah Taurat dalam Perjanjian Lama tidak dimengeri sebagai hukum yang terkait dengan pengadilan melainkan meruju kepada pengajaran atau instruksi yang berisi tentang perintah dan tuntunan etika umum. ${ }^{7}$

Lebih lanjut Osborne menjelaskan mengenai pembacaan terhadap hukum taurat harus diklasifikasikan pada empat kumpulan hukum yang ada dalam pentateukh. Pertama, ada dekalog dan kitab kovenan yang diberikan di Sinai dalam Keluaran 20-23 dan ditegaskan kembali dalam Keluaran 34, Dalam Dekalog menyediakan peraturanperaturan untuk hubungan kovenan antara Allah dan Israel yang memaparkan prinsipprinsip hubungan kovenan tersebut. Hukum ini paling dekat dengan bentuk apdiktik atau tanpa syarat-syarat. Kedua adalah hukum tabernakel dalam Keluaran 25-40 mengenai pengarahan-pengarahan Allah mengenai pembangunan kemah suci. ${ }^{8}$ Yang ketiga adalah hukum-hukum ritual berkenaan dengan mezbah dan berakhir dengan aturan penyembahan dan yang keempat adalah serangkaian khotbah yang disampaikan oleh Musa di dataran Moab sebelum Israel memasuki tanah Kanaan (Ul1:6-4:40; 5: 126:19; 27: 1-28:68; 29:1-30:20). ${ }^{9}$

Berdasarkan pada klasifikasi hukum dalam pentateukh, Darel Bock seperti yang dikutip oleh Osborne menawarkan lima usulan tentang bagaimana orang Kristen dapat memahami hukum taurat (1) sebagai kitab suci yang diinspirasikan oleh Allah yang memiliki relevansi etika dan theologis pada masa kini (2) Pengenalan akan hukumhukum Perjanjian Lama (3) mnghormati perbedaan-perbedaan yang ada dan menggunakan keterangan-keterangan dari latar belakang budaya untuk mendapatkan pesan theologisnya (4) harus menyelidiki dasar-dasar theologis dan fungsi-fungsi sosial dari setiap peraturan individual untuk mengerti signifikansi dan setelah itu menentukan relevansi permanen dari setiap peraturan tersebut (5) Kita harus mengkontekstualisasi prinsip-prinsip dasar dari hukum dan budaya dalam konteks tertentu dan menerapkannya dengan tepat pada situasi masa kini. ${ }^{10}$

Hukum Taurat adalah hukum yang bersifat mengikat dan bukan hanya sekadar bayang-bayang Kristus, hukum Taurat diterapkan secara langsung sama seperti Perjanjian Baru Oleh karena itu maka perlu untuk mencari tahu makna aslinya, mengerti kekhususan budaya dan menerapkan pesan teologinya secara langsung kepada kita di

\footnotetext{
${ }^{7}$ Grant R. Osborne, The Hermeneutical Spiral: A Comprehensive Introduction to Biblical Interpretation (Revised and Expanded Edition; Downers Grove, Illinois: IVP Academic, 2006),212.

${ }^{8}$ Pembangunan kemah suci ini adalah kontras dari peristiwa anak lembu emas yang dianggap sebagai perlawanan terhadap perintah jangan ada padamu Allah lain dihadapan-Ku, dengan pembangunan kemah suci Allah sedang mengambil tempat kediaman di antara umat-Nya

9 Ibid

10 Ibid
} 
masa kini. Dengan kata lain kita harus menentukan tujuan-tujuan theologisnya dan menerapkannya pada situasi-situasi terkini. ${ }^{11}$

Senada dengan Osborne, Gordon Fee dalam buku hermeneutika yang dikarang juga memberikan pembahasan khusus mengenai bagaimana menafsirkan kitab Taurat, ${ }^{12}$ selain sejumlah genre PL dan PB yang sudah disebutkan dalam ulasan tulisan Osborne dan Sutanto di atas. Dalam hal menafsirkan isi kitab taurat, Fee dan Stuart memberikan beberapa saran praktis yaitu

Lihatlah Taurat Perjanjian Lama sebagai Firman Allah dan jangan melihat Taurat Perintah langsung Allah kepada saudara Lihatlah Taurat Perjanjian Lama sebagai dasar untuk Perjanjian yang lama dan karenanya dasar untuk sejarah Israel, janganlah melihat Taurat Perjanjian Lama sebagai hal yang mengikat orang Kristen dalam perjanjian yang baru Lihatlah keadilan, kasih serta norma-norma yang tinggi dari Allah yang sepadan dengan rahmat Allah Janganlah menganggap Taurat sebagai petunjuk-petunjuk teknis yang lengkap mengenai segala sesuatu Ingatlah bahwa inti seluruh hukum Taurat (10 Perintah) diulang dalam kitab nabi-nabi dan di baharui dalam Perjanjian Baru Pandanglah taurat sebagai karunia yang dermawan kepada orang Israel yang membawa berkat apabia ditaati, dan jangan menganggap Taurat sebagai sekelompok aturan yang menyebalkan dan membatasi. ${ }^{13}$

Hal itu berarti dalam bagian ini yang akan penulis lakukan adalah melakukan penafsiran induktif dan deduktif, yaitu dengan memperhatikan gramatical dari teks tersebut dengan meneliti tentang struktur kebudayaan yang melatar belakangi sepuluh perintah dan juga membuat perbandingan dengan narasi paralel dari teks yang membahas secara khusus mengenai perintah kedua serta juga melihat perintah kedua ini dari perspektif Perjanjian Baru yang terintegrasi dalam interaksi dengan para penafsir yang telah menafsirkan bagian ini.

\section{Observasi Lexical}

\section{Terjemahan Literal}

\begin{tabular}{|c|c|c|c|}
\hline Ayat & Subjek & Terjemahan & Pemenggalan Teks Ibrani \\
\hline 3 & Manusia & $\begin{array}{l}\text { Jangan ada allah lain di depan } \\
\text { kehadiran ku }\end{array}$ & 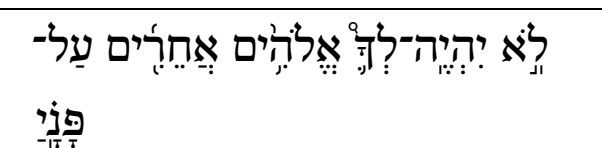 \\
\hline 4 & Manusia & $\begin{array}{l}\text { Janganlah membuat untuk mu } \\
\text { patung seperti apapun yang ada } \\
\text { di langit di atas dan yang di } \\
\text { bumi atau di dalam air, di } \\
\text { bawah bumi }\end{array}$ & 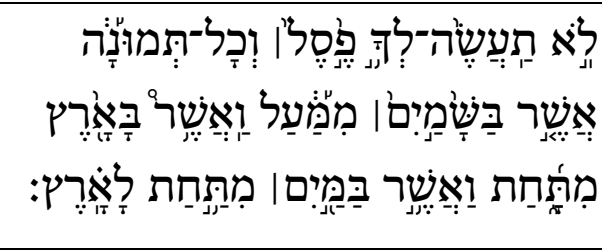 \\
\hline
\end{tabular}

11 Ibid

12 Gordon D. Fee dan Douglas Stuart, Hermeneutik: Bagaimana Menafsirkan Firman Tuhan dengan Tepat!, 113-136

13 Ibid, 163 


\begin{tabular}{|c|c|c|c|}
\hline $5-6$ & $\begin{array}{c}\text { Manusia } \\
\text { dan } \\
\text { Allah }\end{array}$ & $\begin{array}{l}\text { Janganlah sujud menyembah } \\
\text { kepadanya, dan janganlah } \\
\text { beribadah kepadanya karena } \\
\text { akulah TUHAN Allah, Allah yang } \\
\text { cemburu yang membalaskan } \\
\text { kesalahan bapa kepada anak- } \\
\text { anaknya, kepada keturunan } \\
\text { yang ketiga dan keempat dari } \\
\text { orang-orang yang membenci } \\
\text { Aku, tetapi Aku menunjukkan } \\
\text { kasih setia kepada beribu-ribu } \\
\text { orang, yaitu mereka yang } \\
\text { mengasihi Aku dan yang } \\
\text { menjaga pada perintah- } \\
\text { perintah-Ku. }\end{array}$ & 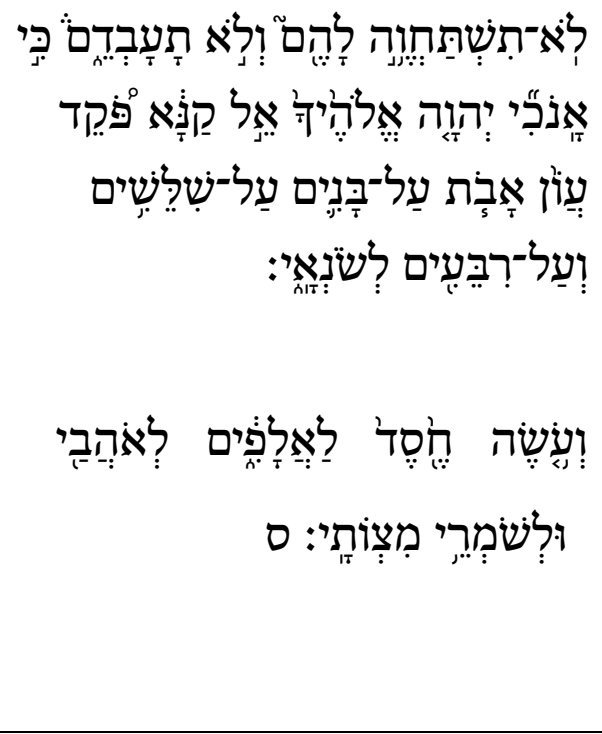 \\
\hline
\end{tabular}

\section{Analisis Kata dan Tata Bahasa}

\section{Ayat 3}

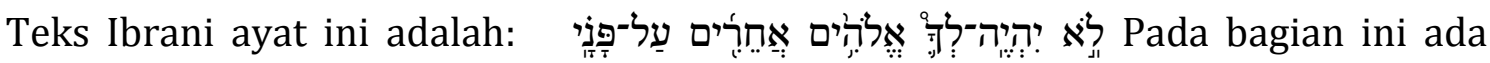
beberapa kata yang perlu dijelaskan, kata לֶא (lo) adalah bentuk negasi yang berarti

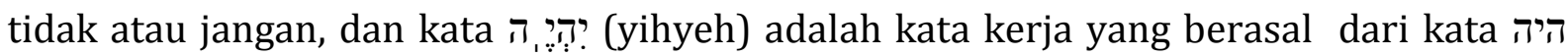
(hyh) yang merupakan kata kerja qal imperfect, orang ketiga tunggal maskulin, yang berarti ada atau berada namun dapat diartikan juga dengan kata beriman kepada sesuatu, sedangkan preposisi, ? merupakan akhiran tambahan yang menunjukan kepada akhiran orang kedua tunggal. Lalu kata Elohim yang diterjemahkan menjadi kata 'allah' merupakan bentuk jamak dari kata benda el atau eloah. Elohim adalah kata benda umum maskulin jamak absolute atau jamak kemuliaan, dalam terjemahan bahasa Inggris: "Gods, God". ${ }^{14}$ Dalam terjemahan ITB yaitu "Allah".

Kata Elohim ini adalah kata yang dapat digunakan dengan pengertian tunggal yang menunjuk kepada 'Allah' atau dengan perngertian jamak yang menunjuk pada 'dewadewa'. Kata ini jika di pakai dalam bentuk jamak merupakan jamak kemuliaan. Walau bangsa Israel percaya kepada Allah yang Maha Esa yang tidak mungkin dijamakkan, namun penggunaan bentuk jamak untuk menyebut Allah digunakan sebagai wujud penghormatan. Bagi mereka, penggunaan bentuk tunggal tidak memadai untuk menyebut Allah. Itulah sebabnya, walau mereka menganut monoteisme, namun mereka tetap menggunakan bentuk jamak untuk menyebut Allah. ${ }^{15}$

Lalu kata di depan ku ('alpanay) yang lebih tepat diterjemahkan 'Before my present' yang menunjuk pada sebuah pertarungan antara dua hal, kata ini dapat juga diterjemahkan dengan kata 'dibandingkan dengan'. Martin Noth dalam uraiannya tentang kata ini menjelaskan bahwa 'alpanay, seharusnya diterjemahkan dengan

\footnotetext{
${ }^{14}$ Haris, et al, Theological Wordbook of the Old Testament Vol. 1, 41.

15 David L. Baker, dkk., Pengantar Bahasa Ibrani (Jakarta: BPK Gunung Mulia, 2004), 98.
} 
terjemahan "before me," had a cultic meaning in this passage. ${ }^{16}$ Dalam asersi Noth ini, kata ini dapat diartikan bahwa hanya Allah (YHWH) saja yang boleh disembah dalam kultus keagamaan orang Yahudi. Sedangkan menurut penafsir Yahudi pada abad pertengahan Abraham ibn-Ezra and Moshe ben Nachman (Ramban atau Nachmanides) memahami kata 'al-panay dalam konotasi geography. Berbeda dengan Noth, asersi dari para penafsir Yahudi ini lebih ingin menunjukkan bahwa di mana saja, di dunia ini hanya Allah saja yang boleh disembah. Sedangkan menurut Rabbi Shelomo ben Yitshaq (aka Rashi), penafsir Yahudi yang paling terkenal kata ini harusnya diterjemahkan dengan terjemahan "before my presence" namun dalam indikasi temporal s sehingga mendapat implikasi "as long as God exists,"atau dengan kata lain "forever and ever. ${ }^{17}$

\section{Ayat 4}

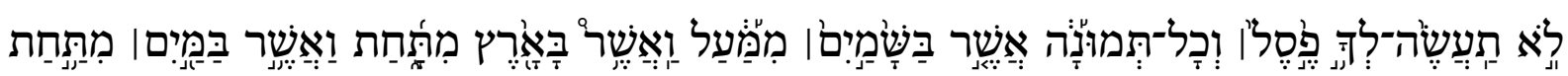

Kata pesel yang diterjemahkan menjadi 'patung' dalam bahasa Indonesia dan carved image dalam bahasa Inggris. Kata ini dalam Alkitab muncul kurang lebih 54 kali, dan kata ini selalu merujuk kepada 'berhala' di dalam Perjanjian Lama. ${ }^{18}$

Secara etimologis kata ini relevan dengan kata kerja לָָָָ yang berarti 'to cut or carve', sejajar dengan kata benda פסל, yang berarti “a carved thing"yang kemudian diterjemahkan dalam bahasa Inggris menjadi kata: "graven image', yang mana di dalam Perjanjian Lama selalu merujuk kepada sebuah obyek buatan tangan manusia. ${ }^{19}$ Hayward menulis, "Whatever else [ פסל ] may signify, it clearly refers to a concrete object, something which may be handled and perceived by the senses." 20 Senada dengan itu, Childs juga menjelaskan "it is generally agreed that the prohibition of making a pesel refers, first of all, to an image carved of wood or stone." 21

Selain itu, kata ini juga dimaknai juga sebagai hasil buatan tangan manusia yang dipercaya memiliki kekuatan dan juga yang digunakan dalam proses penyembahan atau

16 Martin Noth, Exodus: A Commentary (Translated from the German 1959 by John S. Bowden; Old Testament Library; Philadelphia: Westminster, 1962) 162.

17 Ibid

18 Ada kurang lebih 60 kali penggunaan dari akar kata ini,6 kali penggunaan ada dalam bentuk kata kerja dan 54 kali dalam bentuk kata benda. Ada dua perbedaan bentuk lexical yaitu kata benda ל ס ,

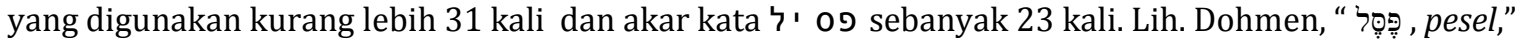
TDOT 12:33.

${ }^{19}$ Barr, The Semantics of Biblical Language (Oxford: Oxford University Press, 1961), 107- 160; Silva, Biblical Words and their Meaning: An Introduction to Lexical Semantics (Grand Rapids: Zondervan, 1983), 35-52.

${ }^{20}$ Hayward, "Observations on Idols in Septuagint Pentateuch," in Idolatry (ed. Barton; London: T\&T Clark, 2007), 422.

21 Childs, Exodus: A Commentary (London: SCM, 1974), 404. 
dengan kata lain, buatan tangan manusia yang diakui sebagai sesembahan (dewa) bagi mereka yang mempercayainya. ${ }^{22}$

Kata ini kemudian diterjemahkan ke dalam bahasa Yunani (LXX) dengan kata eidolon. Kata eidolon sendiri sebenarnya memiliki makna yang sedikit berbeda dengan kata pesel, karena jika pesel menekankan pada sesuatu yang lebih bersifat material, kata eidolon justru merujuk kepada sesuatu yang immaterial.

\section{Ayat 5-6}

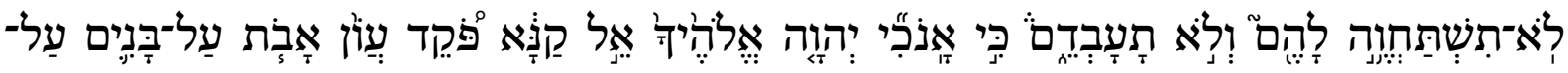

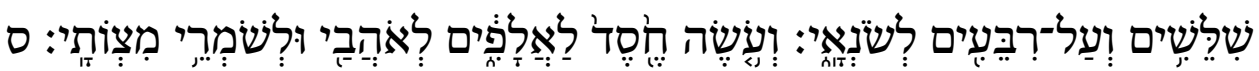

Kata menyembah adalah dari kata tacabedem yang diambil dari akar kata cbd yang berarti kerja, melayani. Kata ini digunakan juga dalam hukum keempat tentang hari sabat, enam hari lamanya engkau akan bekerja ( $t a^{c a} b o d$ ) dan melakukan segala pekerjaan (Kel 20:9). Kata ini diterjemahkan ke dalam bahasa Ingrgris 'worship'.

Kata 'menghukum (poqed) dari akar kata pqd yang dalam perkembangannya merupakan kata yang selalu dihubungkan dengan penghukuman yang bersifat militer. Kata ini lebih sering digunakan pada kondisi di mana seorang prajurit yang berada di bawah perintah dari atasan mendapatkan penghukuman karena kesalahan yang dia perbuat

\section{Hasil dan Pembahasan}

\section{Tafsir Keluaran 20:3 (4)-6}

Secara umum perintah kedua ini dapat dibagi dalam 4 bagian besar yaitu : (1) larangan (2) alasan dari larangan tersebut (3) Peringatan (4) janji. Untuk bagian pertama tentang larangan adalah jelas berkaitan dengan penyembahan kepada berhala, yang dimaksud dengan berhala adalah sesuatu yang dibuat atau merupakan hasil karya manusia dalam bentuk batu, patung, emas atau lain sebagainya. ${ }^{23}$ Poin utamanya bukanlah bahwa Allah melarang penggunaan alat-alat tersebut, karena pada dasarnya Allah juga mengijinkannya dalam pembangunan tabut perjanjian dan kemah suci.

Berfirmanlah TUHAN kepada Musa: 2 "Lihat, telah Kutunjuk Bezaleel bin Uri bin Hur, dari suku Yehuda, ${ }^{3}$ dan telah Kupenuhi dia dengan Roh Allah, dengan keahlian dan pengertian dan pengetahuan, dalam segala macam pekerjaan, ${ }^{4}$ untuk membuat berbagai rancangan supaya dikerjakan dari emas, perak dan tembaga; ${ }^{5}$ untuk mengasah batu permata supaya ditatah; untuk mengukir kayu dan untuk bekerja dalam segala

22 E.g. Hyatt, Commentary on Exodus (London: Oliphants, 1971), 211; Durham, Exodus (Waco, TX: Word, 1987), 285. Hal yang menarik adalah bahwa kata ini tidak pernah digunakan merujuk kepada gambar-gambar yang berkaitan dengan ritus Israel, misalnya pohon palem, kerubim, dan hiasan-hiasan yang ada di dalam ritus Israel.

${ }^{23}$ Philip Graham Ryken, Exodus: Saved for God's Glory (Wheaton, Illinois: Crossway Books, 2005), 
macam pekerjaan. ${ }^{6}$ Juga Aku telah menetapkan di sampingnya Aholiab bin Ahisamakh, dari suku Dan; dalam hati setiap orang ahli telah Kuberikan keahlian. Haruslah mereka membuat segala apa yang telah Kuperintahkan kepadamu (Kel.31:1-6).

Meskipun demikian, Tuhan telah memberikan kemampuan dan juga perintah untuk membuat perhiasan untuk bait suci dan tabut perjanjian, tetaplah bahwa larangan untuk membuat patung yang menyerupai apapun di langit, bumi maupun di bawah bumi adalah sesuatu yang dilarang. Ryken menulis

In other words, the Israelites were not allowed to represent God in the form of anything in all creation. Remember that the Israelites had been living with the Egyptians, who worshipped many gods, nearly all of which they represented in the form of animals. The god Horus had the head of a falcon, the god Anubis had the head of a jackal, and so on...But the God of Israel refused to be represented in the image of any of his creatures. ${ }^{24}$

Larangan mengenai pembuatan patung ini dapat ditarik dari landasan berpikir berkaitan dengan iconography dalam dunia pagan di tempat di mana bangsa Israel hidup, dalam konteks dunia pagan, penyembahan berhala selalu diidentikkan dengan adanya patung-patung yang mewakili keilahian dari dewa-dewa tesebut, patung-patung tersebut mewakili gambaran dari apa yang dilarang dari perintah kedua ini.

Selain itu dalam larangan mengenai pembuatan dan penyembahan terhadap patung ini sedang melegetimasi tentang Allah sebagai satu-satunya yang tertinggi di dalam seluruh alam ciptaan, Dia adalah Allah yang transenden, sekaligus larangan ini sedang mengajarkan tentang bagaimana Allah berelasi dengan segala ciptaan-Nya. Relasi itu tidak ditentukan oleh ciptaan-Nya melainkan didasarkan pada penyataan diri Allah sendiri yang bebas untuk menyatakan diri-Nya tanpa harus dikurung (dikungkung) oleh benada-benda material.

Bagian kedua mengenai alasan dari larangan ini adalah karena Allah adalah Allah yang cemburu. Kata cemburu ini adalah kata yang merujuk pada kesetiaan Allah pada janji-Nya. Kata cemburu di dalam teks Bahasa Inggris diterjemahkan dengan kata 'Jealousy" ketimbang menggunakan kata Envy, hal ini disebabkan karena kata Envy merujuk kepada suatu keadaan egois sedangkan kata jealousy lebih bersifat rasa memiliki yang benar. Allah adalah Allah yang cemburu untuk menunjukkan kesempurnaan dari kasih-Nya, di mana di dalam kasih-Nya Allah tidak ingin umat-Nya mencintai yang lain.

Bagian ketiga adalah mengenai peringatan. Peringatan ini diberikan sebagai warning agar perintah ini dilaksanakan dengan sungguh-sungguh, karena akibat dari melanggar perintah ini adalah penghukuman yang sangat keras. Hal ini terlihat dalam sejarah bangsa Israel, yaitu ketika bangsa Israel telah masuk ke dalam tanah Kanaan dan kemudian mulai terjebak dalam penyembahan berhala, Allah kemudian menghukum

24 Ibid, 569 
bangsa Israel dengan cara membiarkan mereka mengalami penindasan dari bangsabangsa sekitar dan puncaknya terjadi ada masa Salomo ketika Salomo jatuh dalam penyembahan berhala dan Allah menghancurkan kerajaannya serta membuangnya Yehuda ke Babel dan Kerajaan Israel Utara ke kerajaan Asyur sampai tidak ada yang tersisa dari bangsa Israel utara.

Dan yang keempat adalah janji bahwa Allah akan menunjukkan kasih setia-Nya kepada mereka yang berpegang kepada perintah ini. Hal ini terlihat pada kehidupan Daniel, Sadrak, Mesakh dan Abednego, di mana melalui ketaatan mereka terhadap larangan ini, Allah menjaga mereka dari penindasan dan kesulitan-kesulitan.

\section{Implementasi Keluaran 20:3(4)-6 Bagi Yudaisme}

Untuk memahami bagaimana orang Yahudi mengimplementasikan larangan kedua ini, hal yang perlu dijelaskan terlebih dahulu adalah berkaitan dengan latar belakang dari Yudaisme itu sendiri khususnya berkaitan dengan larangan-larangan yang ada dalam kitab Musa. Perintah-perintah yang tersebar dalam kelima kitab Musa ini, telah dikelompokkan oleh para Rabi Yahudi dan didapati ada 613 perintah yang disebut dengan taryag mitsvot, dari 613 perintah ini, 248 nya berisi kalimat negatif atau larangan yang ditandai dengan penggunaan kata 'jangan' sedangkan sisanya yaitu 365 merupakan perintah yang bersifat positif atau yang merupakan anjuran. ${ }^{25}$

Lebih lanjut dijelaskan bahwa keseluruhan hukum yang berjumlah 613 ini sebenarnya merupakan penjabaran dari sepuluh (10) larangan Allah yang diberikan oleh Allah kepada Musa di gunung Sinai. Kesepuluh larangan Allah ini dimaknai sebagai pusat sekaligus merupakan simbol dari perjanjian antara Allah dan Israel, karena sepuluh larangan Allah ini adalah larangan yang secara langsung Allah berikan sebagai perjanjian yang bersifat privilege antara Allah dan bangsa Israel.

Kesepuluh larangan Allah ini begitu penting bagi Yudaisme sehingga selalu menjadi bagian tidak terpisahkan dari liturgi perayaan-perayaan Yudaisme, misalnya pada hari pentakosta, kesepuluh larangan Allah ini selalu dibacakan dan diperdengarkan bagi seluruh jemaat. ${ }^{26}$

25 Pembagian ini adalah sesuatu yang menarik, karena dalam penjelasan mengenai pembagianpembagian ini, para Rabi kemudian menjelaskan bahwa 365 perintah yang bernada positif merujuk kepada 365 hari dalam setahun kalendar, sedangkan 248 perintah yang bernada negatif itu merujuk kepada jumlah 248 tulang dalam diri manusia, kemudian hal ini dimaknai bahwa perintah ini dimengerti sebagai simbolisasi kehidupan manusia dalam satu tahun, dan 248 merujuk kepada internalisasi hukum itu dalam diri seseorang yang menunjukkan keyahudian orang tersebut. (Penjelasan ini dapat ditemui pada midrash tehillim 104:2)

${ }^{26}$ Sepuluh perintah Allah ini, memang sengaja di baca pada hari pentakosta, karena dipercaya secara tradisi bahwa Musa menerimanya di gunung Sinai tepat setelah 7 minggu dari hari raya Paskah yang pertama bagi bangsa Israel di tanah Mesir. Juga ada aturan yang mengetaur untuk membaca kesepuluh perintah ini, bahwa jika sepuluh perintah ini akan dibacakan, mesti dibacakan sambil berdiri dan semua yang mendengarnya juga harus berdiri untuk menghormatinya meskipun kesepuluh perintah ini tidak lebih tinggi dari 603 perintah lainnya. Lih. Nahum Sarna, Exploring Exodus (New York: Shocken, 1986) $141-42$ 
Mengenai kesepuluh larangan Allah sendiri, ditemukan memiliki dua versi yaitu (Keluaran 20:2-14 dan Ulangan 5:6-18), perbedaannya terletak pada hukum keempat yaitu berkaitan dengan perintah untuk menghormati hari sabat, di mana ditemukan beberapa tambahan dan perubahan redaksi kalimat dari perintah keempat.

\begin{tabular}{|c|c|}
\hline Keluran 20: 8-11 & Ulangan 5: 12-15 \\
\hline $\begin{array}{l}{ }^{8} \text { Ingatlah dan kuduskanlah hari Sabat: } \\
9 \text { enam hari lamanya engkau akan } \\
\text { bekerja dan melakukan segala } \\
\text { pekerjaanmu, } \\
10 \text { tetapi hari ketujuh adalah hari Sabat } \\
\text { TUHAN, Allahmu; maka jangan } \\
\text { melakukan sesuatu pekerjaan, engkau } \\
\text { atau anakmu laki-laki, atau anakmu } \\
\text { perempuan, atau hambamu laki-laki, } \\
\text { atau hambamu perempuan, atau } \\
\text { hewanmu atau orang asing yang di } \\
\text { tempat kediamanmu. } \\
11 \text { Sebab enam hari lamanya TUHAN } \\
\text { menjadikan langit dan bumi, laut dan } \\
\text { segala isinya, dan Ia berhenti pada hari } \\
\text { ketujuh; itulah sebabnya TUHAN } \\
\text { memberkati hari Sabat dan } \\
\text { menguduskannya. }\end{array}$ & $\begin{array}{l}12 \text { Tetaplah ingat dan kuduskanlah hari } \\
\text { Sabat, seperti yang diperintahkan } \\
\text { kepadamu oleh TUHAN, Allahmu. } \\
13 \text { Enam hari lamanya engkau akan } \\
\text { bekerja dan melakukan segala } \\
\text { pekerjaanmu, } \\
14 \text { tetapi hari ketujuh adalah hari Sabat } \\
\text { TUHAN, Allahmu; maka jangan } \\
\text { melakukan sesuatu pekerjaan, engkau } \\
\text { atau anakmu laki-laki, atau anakmu } \\
\text { perempuan, atau hambamu laki-laki, } \\
\text { atau hambamu perempuan, atau } \\
\text { lembumu, atau keledaimu, atau } \\
\text { hewanmu yang manapun, atau orang } \\
\text { asing yang di tempat kediamanmu, } \\
\text { supaya hambamu laki-laki dan } \\
\text { hambamu perempuan berhenti seperti } \\
\text { engkau juga. } \\
\text { 15 Sebab haruslah kauingat, bahwa } \\
\text { engkaupun dahulu budak di tanah } \\
\text { Mesir dan engkau dibawa keluar dari } \\
\text { sana oleh TUHAN, Allahmu dengan } \\
\text { tangan yang kuat dan lengan yang } \\
\text { teracung; itulah sebabnya TUHAN, } \\
\text { Allahmu, memerintahkan engkau } \\
\text { merayakan hari Sabat. }\end{array}$ \\
\hline
\end{tabular}

Para penafsir melihat bahwa perbedaan antara Keluaran dan kitab Ulangan ini disebabkan karena adanya kepentingan-kepentingan teologis yang melatarbelakangi mengapa ada penambahan frasa di dalam kitab Ulangan. ${ }^{27}$ Dengan mengamati bahwa sepuluh perintah Allah begitu penting bagi orang-orang Yahudi, maka dapat dipastikan

\footnotetext{
27 Menurut studi kritis, yang diterima umum bahwa kitab ulangan adalah kitab yang ditulis atau direkonstruksi pasca pembuangan dari Kerajaan Israel utara (Samaria) oleh bangsa Asyur, sehingga para penyusun kitab ini yang lebih dikenal dengan istilah Deuteronomist (D) sengaja memberi tambahan redaksi kalimat terhadap hukum keempat ini dengan kepentingan untuk mengajar bangsa Israel bahwa salah satu alasan dari pembuangan yang terjadi kepada mereka adalah karena pelanggaran terhadap hari sabat Tuhan, itulah mengapa ada penekanan mengenai perbudakan di Mesir. lih E.g. Brueggemann, Deuteronomy (Nashville: Abingdon, 2001), 50; bnd Römer, The So-called Deuteronomistic History: A Sociological, Historical and Literary Introduction (London: T\&T Clark,2007), 173
} 
bahwa pelanggaran terhadap salah satu hukum itu akan menimbulkan hukuman yang cukup berat bagi mereka yang melanggarnya.

Dan salah satu perintah dari kesepuluh perintah itu adalah larangan untuk membuat dan menyembah patung dalam bentuk apapun di bumi ini. Larangan inilah yang juga mendasari pandangan teologi dari Yudaisme tentang Allah bahwa Allah adalah Allah yang tidak terbatas sehingga tidak ada satu gambaran apapun apalagi patung yang dapat digunakan untuk merepresentasikan kehadiran Allah, bagi Yudaisme, dengan kata lain, patung tidak dapat digunakan sebagai sarana untuk penyembahan kepada Allah, hal ini dipertegas dalam Imamat 26:1 "Janganlah kamu membuat berhala bagimu, dan patung atau tugu berhala janganlah kamu dirikan bagimu; juga batu berukir janganlah kamu tempatkan di negerimu untuk sujud menyembah kepadanya, sebab Akulah TUHAN, Allahmu.

Memang ada beberapa penafsir yang melihat bahwa tafsir terhadap hukum kedua ini sudahlah tidak penting lagi karena hukum ini diberikan kepada orang Israel dan hanya berguna bagi bangsa Israel saja pada saat itu dan tidak dapat diterapkan pada masa kini. Misalnya Von Rad yang menuliskan "In the history which Israel herself wrote of herself, she believed that the commandment which forbade images had been revealed from the time of Moses onwards. This view has again and again been vehemently disputed down to the present day."28

Namun, jika dipahami berkaitan dengan hermeneutik Alkitab itu sendiri, maka kita dapat sebuah kesimpulan sederhana, bahwa Alkitab memang ditulis untuk mereka tetapi penulisan itu adalah bagi kita, maka kita perlu untuk melihat terlebih dahulu bagaimana orang Israel memaknai perintah kedua ini dalam sejarah mereka. Salah satu penafsir yang patut dijadikan sebagai rujukan tentang bagaimana kaum yudaisme memaknai perintah ini adalah Philo yang hidup pada abad pertama, dalam bukunya $D e$ Decalogo, Philo menjelaskan tentang bagaimana ayat ini dimaknai dan ditafsirkan oleh orang-orang Yahudi sebagai sebuah perintah yang bersifat keras.

Philo melandaskan penafsirannya terhadap perintah kedua ini dari terjemahan Alkitab bahasa Yunani (LXX). Dalam tafsir Philo terhadap perintah kedua ini, Philo menjelaskan bahwa larangan untuk jangan ada padamu Allah lain dihadapanku seharusnya dimaknai dengan memperhatikan perintah selanjutnya yaitu dengan jangan membuat patung,, jadi larangan mengenai allah lain mengacu kepada patung tersebut dan hal ini merupakan kesatuan, karena kata patung פ yang digunakan dalam konteks ini adalah selalu mengacu kepada objek penyembahan. ${ }^{29}$ Dengan kata lain

${ }^{28}$ von Rad, Old Testament Theology (trans. Stalker; 2 vols.; vol. 1; Edinburgh: Oliver and Boyd, 1962), 215

${ }^{29}$ Kata ini pernah digunakan dalam konteks Greco-Roman dan selalu merujuk kepada penggunaan untuk patung dari dewa-dewa Greco Roman. Lih. T. Griffith, 'EI $\Delta \Omega \Lambda O N$ as "Idol” in Non-Jewish and NonChristian Greek', Journal of Theological Studies, NS, 53.1 (2002), pp. 95-101 
bahwa, larangan mengenai jangan ada padamu Allah lain, adalah merupakan satu perintah dengan larangan membuat patung.

Juga di dalam Midrash yang memuat tafsiran terhadap kitab Keluaran Sifre Bemidbar, didapati bahwa para penafsir Yahudi menjadikan hukum pertama (Kel.20:3) dan hukum kedua (Kel. 20:4-6) ini adalah menjadi satu bagian, yaitu dengan tidak memisahkan antara larangan memiliki Allah lain dan menyembah patung. ${ }^{30}$ Pendapat ini didasari bahwa kalimat pembukaan dari kesepuluh hukum ini yang bernada normatif adalah dianggap sebagai hukum yang pertama. ${ }^{31}$

Dalam tafsir terhadap hukum ini, Yudaisme memaknai ayat ini sebagai larangan untuk membuat patung apapun, karena larangan pembuatan patung itu sendiri didahului oleh larangan untuk memiliki Allah lain. Hal ini diperkuat melalui tafsiran mereka dalam Mekilta, bagian dari Midrash tentang kitab Keluaran yang menjelaskan bahwa ungkapan dari 'allah lain' adalah merujuk kepada hasil karya manusia (Yesaya 37:19). ${ }^{32}$ Berdasarkan pada pemahaman inilah, kemudian di dalam Yudaisme tidak mengenal patung sebagai media dalam ritual ibadah mereka, Yudaisme adalah agama yang muncul dari pendengaran dari sesuatu yang lebih bersifat lisan ketimbang bersifat visual. $^{33}$

Namun hal ini tidak serta merta menjadikan Yudaisme lepas dari iconography secara total, dalam pembacaan terhadap kitab Musa, di dapati bahwa Musa yang begitu berhati-hati dengan iconography pun justru terjebak dalam iconography. Salah satu contohnya adalah kisah mengenai bagaimana reaksi Musa berkaitan dengan penyembahan Anak lembu emas dan juga tentang patung ular tembaga (Bil.21:4-9) yang akhirnya membuat orang Israel terjebak dalam penyembahan berhala pada kemudian hari (2 Raja 18:4). Selain itu juga kita dapat melihat bagaimana iconography telah menjadi bagian dari perjalanan bangsa Israel, ini dapat kita lihat dalam Keluaran 31, yang mengisahkan tentang Bezaleel yang dipenuhi dengan roh Allah untuk membuat segala macam pekerjaan yang berkaitan dengan iconography (Kel.31:2-4) terutama

\footnotetext{
30 Perbedaan itu sendiri tampak juga di dalam Kekristenan, di mana Gereja Katolik dan juga Lutheran menganggap bahwa hukum kedua adalah pelarangan penyebutan nama Tuhan dan bukan pelarangan berkaitan dengan pembuatan patung, sedangkan larangan untuk mengingini justru yang dibagi menjadi dua yaitu larangan mengingin isteri sesama sebagai satu hukum tersendiri dan larangan untuk memiliki harta orang lain sebagai hukum sendiri. Moshe Greenberg, "The Decalogue Tradition Critically Examined," in: Ben-Zion Segal, ed., The Ten Commandments in History and Tradition (Jerusalem: Magnes, 1990) 99; Jeffrey H. Tigay, Deuteronomy (The JPS Torah Commentary; Philadelphia-Jerusalem: Jewish Publication Society, 1996) 63; Moshe Weinfeld, “The Uniqueness of the Decalogue," in: Ben-Zion Segal, ed., The Ten Commandments in History and Tradition (Jerusalem: Magnes, 1990) 6-7 and n. 20

31 Miller, "The Story of the First Commandment: The Book of Joshua," 80

32 Ungkapan 'allah lain' lebih merupakan referensi kepada sesuatu yang dianggap sebagai Allah oleh manusia dan bukan merujuk kepada eksistensi dari keberadaan Allah tersebut. Lih. Mekilta Bakhodesh

33 Jon D. Levenson, Sinai and Zion: An Entry into the Jewish Bible (San Francisco: HarperCollins, 1985) 147-48,
} 
yang berkaitan dengan tabut perjanjian dan kemah pertemuan dengan membuat beberapa iconography misalnya kerubim.

Iconography Yudaisme menjadi lebih bebas ketika Salomo membangun bait Allah dan kemudian mengisinya dengan berbagai perkakas-perkakas bait Allah yang dicatat dalam I Raja-raja 6 dan juga bagaimana ia menghias keseluruhan istanannya dengan patung-patung seperti yang dapat kita baca dalam 1 Raja-raja 7. Selain itu, temuantemuan arkeologi juga memberikan kepada kita begitu banyak bukti mengenai iconography Israel mula-mula sampai pada masa Hizkia dan Yosia Raja Israel sekitar akhir abad ke-8 SM yang melakukan reformasi dengan menyingkirkan semua jenis iconography. ${ }^{34}$

Meskipun bangsa Israel memiliki banyak ragam iconography, namun sekali lagi bahwa orang Israel memaknai ayat ini dengan secara literal sehingga di dalam bait suci mereka tidak ada gambar atau patung yang melukiskan atau merepresentasikan tentang Tuhan. ${ }^{35}$ Meskipun jika kita membaca Perjanjian Lama seringkali kita temukan bangsa Israel yang terjerat dalam praktik penyembahan berhala, misalnya meenyembah patung Dagon (dewa orang Filistin), menyembah Patung buatan Yerobeam.

Perintah kedua ini adalah perintah yang terus menerus diulangi dalam setiap pembacaan akan Perjanjian Lama, Allah berulang kali mengingatkan bangsa Israel untuk menjauhkan diri dari bahaya penyembahan berhala melalui iconography ini, bahkan salah satu dosa Salomo yang dicatat dalam I Raja-raja 11:7 adalah berkaitan dengan pendirian kuil-kuil sesembahan yang di dalamnya memuat patung-patung dari dewadewa asing. Pelaksanaan perintah kedua kemudian diteruskan pada masa Yosia menjadi raja Israel dimana dia menjauhkan segala bentuk patung-patung yang ada di Israel, dan dari sini, pemaknaan orang-orang Israel akan perintah kedua ini semakin menunjukkan bentuk yang lebih keras, hal ini juga mungkin yang menjadi latar belakang penulisan kembali kitab Ulangan dan juga perintah dari hukum kedua ini kembali didengungkan dalam kitab Yeremia dan kitab Yesaya serta para Nabi.

Hal ini terlihat dalam Ulangan 7:25-26, Yesaya 40:18-20, Habakuk 2:18-19. Situasi pemaknaan secara harafiah mengenai perintah kedua ini semakin memuncak pada masa ketika Yudaisme mengalami konflik dengan Hellenisme, di mana Yudaisme menolak dengan tegas ideology dan pengaruh kultural Hellenisme terhadap Yudaisme, di mana Hellenisme merupakan pandangan yang mengadopsi begitu banyak patung-patung sebagai sesembahan dan puncaknya adalah perang yang dipelopori oleh wangsa Makabe terhadap Hellenisme yang disebabkan oleh keinginan Anthokius Epifanes IV yang ingin mendirikan patungnya di dalam bait suci Israel yang mana hal itu adalah pelanggaran yang sangat besar terhadap kesucian Allah sebagai yang mewujudkan kehadiran-Nya di

${ }^{34}$ Kemungkinan besar bahwa Kitab Ulangan 16:21-22 yang berisi tentang larangan pembuatan patung dan lain sebagainya ditulis pada masa Josia menjadi raja Israel.

35 Patrick D. Miller, Paul D. Hanson, and S. Dean McBride, eds., Ancient Israelite Religion: Essays in Honor of Frank Moore Cross (Philadelphia: Fortress, 1987) 
dalam bait suci dan yang tentu saja melanggar perintah kedua ini. Hal ini berlanjut juga pada masa pemerintahan Romawi, dimana penggunaan patung-patung bagi Yudaisme selalu diidentikkan dengan praktik penyembahan berhala.

Orang-orang Yahudi mengerti dengan baik larangan perintah kedua ini sehingga mereka tidak pernah mencoba untuk membuat gambaran tentang Allah dalam bentuk apapun karena bagi mereka penggambaran tentang Allah tidak dapat diwakilkan dalam bentuk iconography, justru bagi orang Yahudi dengan berdasarkan pada perintah kedua ini, patung dan lain sebagainya justru merupakan bentuk pengadaan 'allah lain' dihadapan mereka.

Salah satu contoh yang paling konkret berkaitan dengan hal ini adalah kisah yang di catat di dalam Kitab Daniel tentang Sadrak Mesakh dan Abednego (Dan.3) yang menolak untuk menyembah patung karena pemahaman mereka tentang keilahian yang tidak dapat dituangkan dalam bentuk patung. Bagi Yudaisme iconography tentang Allah hanya dapat ditemukan dalam alam ciptaan dan di dalam Firman Allah itu sendiri dan juga ada di dalam Haggadah yang merupakan tafsiran terhadap Perjanjian Lama.

Bagi orang Yahudi, apa yang ditulis di dalam Taurat adalah iconography Allah yang paling sempurna bagi manusia, karena menurut mereka iconography itu berbicara dalam bahasa manusia yang paling mudah untuk dimengerti, hal ini didasarkan kepada Firman itu sendiri dalam Ulangan 4:12.36

Selain itu, gambaran tentang Allah juga hanya dapat ditemukan di dalam alam ciptaan buatan tangan Allah sendiri. Di katakan dalam Mazmur 19 bahwa langit menceritakan kemuliaan Allah dan cakrawala memberitakan pekerjaan tangan-Nya (ay.1), dan ciptaan Allah yang paling dapat merepresentasikan Allah adalah manusia, karena dalam teologi Yudaisme dikatakan bahwa manusia diciptakan menurut gambar dan rupa Allah. Midrash menggambarkannya dengan jelas mengenai hal ini

The whole work of Creation was done by these three [the water, the earth and the heavens] ... When the sixth day came they were all prepared to create, as on the other days. The Holy One, blessed be He, said to them: No single one of you can make this creature, as you have made the other creatures that have been formed up till now. But you must all join together, and I shall be with you, and we shall make man; for you cannot make him on your own. You three will be responsible for the body, and I shall be responsible for the soul... with [the part] that he will receive from Me, namely the soul, he will leave the affairs of the world, and his yearning and desire will be for the holy, supernal things. ${ }^{37}$

Secara sederhana, dalam pemaknaan tentang perintah yang kedua ini, Yudaisme memaknainya sebagai sebuah larangan untuk tidak menjadikan patung dalam bentuk apapun apalagi patung itu dibuat untuk merepresentasikan keilahian dan digunakan

\footnotetext{
${ }^{36}$ Gambaran paling sempurna tentang Taurat itu sendiri ada di dalam Mazmur 119 yang berisi tentang kesempurnaan dari Taurat itu bagi kehidupan manusia.

37 The wisdom of the Zohar, Part IV:2, pp 779-780.
} 
untuk ritual ibadah, karena keilahian tidak dapat dijadikan dalam bentuk apapun, bagi Yudaisme segala bentuk iconography yang diidentikkan dengan keallahan adalah penyembahan berhala dan merupakan pelanggaran terhadap hukum kedua, karena iconography yang sebenarnya tentang Allah adalah terdapat di alam ciptaan, taurat dan di dalam manusia, bahkan tidak dapat dibatasi oleh apapun.

Perintah kedua dimaknai secara literal, sehingga Patung, lukisan, relief atau hal lain sebagainya yang dibuat untuk mempersonafikasikan Allah dan apalagi ditaruh di dalam bait suci Israel adalah pelanggaran terhadap hukum kedua dari sepuluh perintah Allah.

\section{Zaman Yesus}

Tidak banyak catatan di dalam Injil tentang implementasi keluaran 20:4-6 ini. Namun jika menilik dari periode intertestamental di mana konflik berkaitan dengan iconography yang dilatar belakangi oleh perintah kedua ini mencapai puncaknya dengan pemberontakan wangsa Makabe maka tidak diragukan lagi bahwa masa ini juga pengimplementasian dari keluaran 20:4-6 ini tidak jauh berbeda. Yesus tidak pernah secara langsung menyinggung perintah kedua ini dalam pengajaran-Nya maupun di dalam konfrontasinya dengan para pemuka agama Yahudi atau para pemimpin Romawi yang berkuasa pada saat itu.

Namun Yesus dalam khotbahnya di bukit mengajarkan bahwa Dia datang bukan untuk meniadakan hukum taurat melainkan untuk menggenapinya (Mat.5:17), dan Yesus juga menyatakan bahwa selama langit dan bumi masih ada, satu iotapun dari hukum itu tidak akan ditiadakan (Mat. 5:18-19), secara implisit hal ini memberikan sebuah asersi bahwa perintah kedua ini pun tetap masih merupakan perintah yang masih berlaku pada masa Yesus, bahkan Yesus dalam percakapannnya dengan seorang muda yang kaya (Mat.19:16-19) memberikan penekanan tentang pentingnya hukum taurat (sepuluh perintah) ini.

Lebih lanjut Matius mencatat dalam Matius 22:37-39 bagaimana Yesus menyimpulkan kesepuluh perintah ini dalam sebuah summary "37 Jawab Yesus kepadanya: "Kasihilah Tuhan, Allahmu, dengan segenap hatimu dan dengan segenap jiwamu dan dengan segenap akal budimu. Itulah hukum yang terutama dan yang pertama. Dan hukum yang kedua, yang sama dengan itu, ialah: Kasihilah sesamamu manusia seperti dirimu sendiri. Pada kedua hukum inilah tergantung seluruh hukum Taurat dan kitab para nabi".

Hal ini menyimpulkan bahwa perintah kedua bagi Yesus adalah sesuatu yang masih berlaku pada masa itu. Pandangan mengenai peritah kedua ini semakin tercermin dalam prolog Injil Yohanes, di mana Yohanes menyatakan bahwa tidak ada seorangpun yang pernah melihat Allah, dan Anak tunggal Allah yang telah menjelma menjadi manusia itulah yang menyatakannya (Yoh.1:14). Teologi tentang Yesus sebagai eikon di dalam Injil Yohanes adalah eskpresi dari diri Ilahi itu sendiri, jika dalam konsep Yudaisme, Alam ciptaan (Maz 19) dan juga Firman Allah merupakan ekspresi dari diri 
Allah, maka Yesus melalui Yohanes menjelaskan bahwa Yesus diperkenalkan sebagai wahyu yang terakhir yang di dalamnya ada segala kepenuhan keallahan.

Pemaknaan keluaran 20:4-6 menurut Yesus bukan ada pada iconography tetapi ada dalam diri-Nya sendiri sebagai gambar Allah yang paling sempurna, sehingga tidak ada iconography apapun yang dapat menggantikan pleroma Allah di dalam dunia selain Yesus sendiri. Dalam Injil Yohanes juga Yesus dalam percakapan dengan perempuan Samaria dalam Yohanes 4:24, menjelaskan bahwa Allah adalah roh, sehingga barangsiapa yang ingin menyembah Allah harus menyembah di dalam roh dan kebenaran, itu berarti bahwa tidak ada personafikasi dalam bentuk apapun yang dapat digunakan dalam proses penyembahan kepada Allah.

\section{Gereja Mula-mula}

Pemaknaan Keluaran 20:4-6 ini menjadi lebih mendapat perhatian pada masa Gereja mula-mula yang dialami oleh para Rasul berkaitan dengan penyembahan berhala, dan Rasul yang paling bergumul dengan persoalan ini adalah Rasul Paulus. Paulus dalam hampir semua surat-suratnya seringkali menyinggung mengenai hal sebagai penyembahan berhala.

Dalam surat Tesalonika yang merupakan surat-surat pertama dari Paulus, Paulus menggambarkan orang-orang Kristen sebagai mereka yang telah berbalik dari berhalaberhala kepada Allah (1 Tes.1:9) ${ }^{38}$, Paulus selalu merujuk kepada para penyembah berhala sebagai mereka yang tidak mengenal Allah (I Kor.12:2) dan yang tidak akan mendapat bagian dalam kerajaan Allah (I Kor.6:9), bahkan Paulus dengan jelas memberikan perbedaan yang cukup kontras antara Kristus (Allah) dengan sesembahan dari bangsa-bangsa asing yang disebut sebagai berhala yang bisu (2 Kor.6:15-16).

Paulus sangat ekstrem terhadap tindakan penyembahan berhala, Paulus dalam surat-suratnya ketika merujuk kepada kata berhala selalu menggunakan kata eidolon, yang adalah kata yang sama dengan terjemahan LXX dari Keluaran 20:4 yang diterjemahkan sebagai patung dalam bahasa Indonesia. Kata eidolon ini sendiri memiliki makna yang luas di dalam Perjanjian Baru yang didalamnya dapat mencakup patung, representasi keilahian, hantu atau sesuatu yang berisfat roh, yang dapat diartikan sebagai patung, lukisan atau apapun yang digunakan untuk merepresentasikan sesuatu yang dianggap ilahi. ${ }^{39}$

Peringatan Paulus yang berangkat dari penafsirannya terhadap perintah kedua ini juga terlihat dengan jelas dalam suratnya kepada jemaat di Roma (Roma 1: 18-32, dimana Paulus menyatakan bahwa patung-patung yang manusia buat adalah

${ }^{38}$ I. H Marshall, 1 and 2 Thessalonians (NCBC; London: Marshall \& Morgan Scott, 1983) 56 1998) 131

${ }^{39}$ D. Newton, Deity and Diet: The Dilemma of Sacrificial Food in Corinth (JSNTSup 169: Sheffield; SAP, 
meruapakan bentuk ketidaktahuan manusia akan Allah bahkan merupakan perlawanan manusia kepada Allah.

Bagi Paulus, Keluaran 20:4-6 merupakan perintah yang harus dilakukan secara harafiah, dimana penggunaan patung atau apapun sebagai representasi dari yang ilahi hanyalah merupakan pelanggaran terhadap perinta yang kedua dan juga merupakan penyembahan berhala. Dalam hal ini terlihat bahwa Paulus menyamakan antara perintah jangan ada padamu Allah lain dihadapanku dengan perintah untuk jangan membuat bagimu patung yang menyerupai apapun.

Bahkan Paulus, meluaskan tafsir terhadap perintah kedua ini, jika perintah kedua hanya melarang pembuataan patung, Paulus justru menambahkannya dengan memberikan argumentasi bahwa makanan yang dipersembahkan kepada berhala juga merupakan hal yang harus dihindari oleh orang percaya, karena dengan memakan makanan yang dipersembahkan kepada berhala, orang percaya secara tidak langsung terlibat dalam penyembahan berhala (I Kor.8-10). ${ }^{40}$

\section{Gereja Reformasi}

Yesus dan Para Rasul secara tegas menolak penggunaan patung (iconography) sebagai alat untuk penyembahan kepada Allah, Gereja mula-mula tidak pernah memvisualisasikan Yesus dalam bentuk iconography (patung relief atau lukisan). Yesus hanya digambarkan dalam bentuk firman yang kemudian dicatat oleh para rasul dan yang diterima sebagai Injil, itulah sebabnya pada masa itu, tidak ada lukisan atau gambar Yesus yang dibuat oleh Gereja mula-mula atau oleh para Rasul yang telah bertatap muka dengan Yesus, bahkan dalam catatan Injil tidak pernah dijelaskan tentang seperti apa wajah dan rupa Yesus.

Dua tokoh Reformasi yang terkenal yaitu Luther dan Calvin juga memiliki pandangan yang berbeda mengenai hukum yang kedua ini. Pandangan Luther kebanyakan dilatar belakangi oleh perdebatannya dengan seorang Reformartor juga yaitu Karlstadt yang dengan tegas menolak penggunaan patung dalam ibadah. Karlstadt menjelaskannya dalam tanggapan dia terhadap Luther dalam 3 poin utama yaitu: "To have images in churches is contrary to the commandment, Thou shalt have no other gods before me. To place idols on the altars is even more devilish. Therefore, we should put them away in obedience to the Scripture." 41

Lebih lanjut, Ia menulis bahwa patung-patung atau iconography tentang Yesus sama sekali tidak memberikan manfaat apa-apa, sehingga patung-patung tersebut harus dihancurkan dan dijauhkan dari dalam Gereja

From the image of the crucified Christ you learn only about the suffering of Christ in the flesh, how his head hung down and the like...Since, then, images are deaf and

\footnotetext{
${ }^{40}$ Survey lebih lanjut mengenai ini dapat dilihat di A. T Cheung, Idol Food in Corinth: Jewish Background and Pauline Legacy (JSNTSup, 1999) 39-81

${ }^{41}$ Andreas Karlstadt, Von Abtuhung der Bilder, ed. H. Lietzmann (Bonn, 1911), 4, quoted in Michalski, Reformation and Visual Arts, 45
} 
dumb, can neither see nor hear, neither learn nor teach and point to nothing other than the pure and simple flesh which is of no use, it follows conclusively that they are of no use. ${ }^{42}$

Dalam tanggapan Luther kepada pandangan Karlstadt ini, Luther lebih memiliki sifat yang lunak dari Karlstadt tentang pemaknaan perintah yang kedua ini, Luther menjelaskan bahwa patung-patung Yesus dan segala bentuk Iconography pada dasarnya idak bertentangan dengan perintah kedua ini, patung itu akan menjadi salah ketika digunakan untuk disembah, tetapi meskipun demikian tidak ada seorangpun yang dapat menolak atau menghancurkan patung-patung kalaupun misalnya patung-patung tersebut dijadikan objek penyembahan, ${ }^{43}$ Luther memberikan analogi dengan adanya orang-orang yang menyembah matahari tetapi itu tidak harus menyebabkan matahari disingkirkan.

But there are many people who worship the sun and stars. Therefore we propose to rush in and pull the sun and the stars from the skies. No, we had better let it be. Again, wine and women bring many a man to misery and make a fool of him [Eccles. 19:2; 31:30]; so we kill all the women and pour out all the wine. Again, gold and silver cause much evil, so we condemn them. Indeed, if we want to drive away our worst enemy, the one who does us the most harm, we shall have to kill ourselves, for we have no greater enemy than our own heart... ${ }^{4}$

Pandangan Luther terhadap iconography ini dapat dirangkum dalam beberapa point penting yaitu: "The Old Testament does not prohibit the use of images only the worship of them. The Old Testament regulations do not apply to the Christian community. The construction of images is a natural function of mankind. Images serve as valuable religious reminders." 45 Bagi Luther, perintah kedua ini tidak dapat diterapkan secara penuh bagi kekristenan, perintah kedua dan sepuluh hukum harus ditafsirkan dalam perspektif yang baru.

Luther percaya bahwa patung dan segala bentuk iconography dapat dijadikan sebagai media pembelajaran bagi orang percaya untuk dapat lebih mendekat kepada Allah. Bagi Luther adalah jelas bahwa perintah pertama (kedua) adalah hanya merupakan larangan untuk membuat patung demi dipakai untuk penyembahan dan bukan pada pembuatan patung secara umum, dalam argumentasinya Luther menjelaskan bahwa Musa yang mendapatkan perintah ini saja kemudian membuat patung kerubim untuk ditaruh pada tabut perjanjian, dan juga membuat patung dari ular tembaga ketika berada di padang Gurun, memang raja Hizkia pada akhirnya

42 A Reformation Debate: Karlstadt, Emser, and Eck on Scared Images, trans. Bryan D. Mangrum and Guiseppe Scavizzi, Renaissance and Reformation Texts in Translation, no. 5 (Toronto: Dovehouse Editions, 1991), 33,

43 Martin Luther, Luther's Works, vol. 51, Sermons I, ed. and trans. John Doberstein (Philadelphia: Muhlenberg Press, 1959), 85.

44 ibid

45 ibid 
menghancurkan patung tersebut bukan karena patung itu sendiri melainkan karena patung itu telah salah digunakan oleh orang Israel. ${ }^{46}$

Lain dari Luther, Calvin seorang reformator sekaligus seorang penafsir juga memiliki pandangan yang berbeda dari Luther. Menurut Calvin sangat jelas bahwa penggunaan patung dan segala bentuk iconography adalah sesuatu yang dilarang di dalam kekristenan karena Allah adalah Allah yang tidak terbatas sehingga tidak dapat ditampung dalam benda material yang terbatas. Dalam penjelasannya Calvin menyatakan bahwa argumentasi ini dibangun berdasarkan kepada kesaksian dari bapak-bapak Gereja mula-mula yang dengan jelas menolak penggunaan iconography dalam ritual penyembahan mereka kepada Allah, ${ }^{47}$ ia menulis:

First, if the authority of the ancient church moves us in any way, we will recall that for about five hundred years, during which religion was still flourishing, and a purer doctrine thriving, Christian churches were commonly empty of images.Thus, it was when the purity of the ministry had somewhat degenerated that they were first introduced for the adornment of churches. ${ }^{48}$

Lebih lanjut, Calvin membangun argumentasi penolakan kepada penggunaan iconography adalah berdasarkan pada tafsirnya terhadap terhadap Perjanjian Lama, di mana menurutnya Allah pertama kali menyatakan diri kepada bangsa Israel itu di dalam suara bukan dalam bentuk rupa (Ul.4:12), itu menunjukkan bahwa memang Allah tidak pernah ingin digambarkan dalam bentuk iconography. 49

Dalam tafsir terhadap Keluaran 20:3-5, Calvin tidak seperti Luther dan tradisi Yudaisme yang menggabungkan kedua peintah ini menjadi satu, Calvin justru memberikan perbedaan anatar perintah jangan ada padamu allah lain sebagai satu perintah, dan jangan membuat bagi mu patung... sebagai satu perintah tersendiri. Ia menulis: "The sum is, that the worship of God must be spiritual, in order that it may correspond to His nature. For although Moses only speaks of idolatry, yet there is no doubt but that by synecdoche, as in all the rest of the Law, he condemns allfictitious services which men in their ingenuity have invented."50

Berdasarkan itu, kemudian Calvin menyimpulkan bahwa adalah sebuah kesalahan jika seseorang mencoba untuk merepresentasikan Allah dalam wujud yang kelihatan karena sesungguhnya Allah tidak dapat terlihat oleh mata manusia. Dalam analisisnya terhadap perintah kedua ini, Calvin memaparkan bahwa memang perintah ini (Kel.20:4-

${ }^{46}$ David C. Steinmetz, "The Reformation and the Ten Commandments," Interpretation 43 no. 3, July $1989,259$.

${ }^{47}$ Pandangan Calvin ini didasarkan kepada Konsili di Elvira pada tahun 305 yang menyatakan bahwa "It is decreed that there shall be no pictures in churches, that what is reverenced or adored be not depicted on the walls." Lih. William A. Dyrness, Reformed Theology and Visual Culture. (Cambridge: Cambridge University Press, 2004)

${ }^{48}$ Alister E. McGrath,A Life of John Calvin. (Oxford: Blackwell Publishers Ltd, 1995). 260

${ }^{49}$ John Calvin, Calvin's Commentaries, vol. 2, The Last Four Books Of Moses Arranged in the Form of a Harmony, trans. Charles William Bingham (Grand Rapids: Baker Books, 2005), 120.

50 Ibid 
6) terdiri dari dua bagian besar yaitu yang pertama larangan pendirian patung dan yang kedua adalah larangan untuk menyembahnya. Dalam asersinya dengan jelas Calvin memberikan penjelasan bahwa sebenarnya pendirian patung secara tidak langsung adalah menghilangkan kemuliaan dari Allah 'every statue that man erects, or every image he paints to represent God, simply displeases God as something dishonorable to his majesty. ${ }^{51}$

Lebih lanjut ia menulis bahwa tidak ada satupun dari ciptaan yang dapat merepresentasikan Allah kecuali Allah sendiri,, bahkan manusiapun dalam bentuk tubuhnya tidak dapat merepresentasikan Allah, ia menulis "We are similar to God only in our souls, and no images can represent him. That is why people who try to represent the essence of God are madmen. God is spirit...all attempts to depict him are an impudent affront...to his majesty and glory." 52

Calvin berdasarkan pada tafsir terhadap Keluaran 20:40-6 ini dengan jelas menolak penggunaan patung atau iconography apapun dalam simbol keagaamaan apalagi sebagai objek untuk penyembahan, meskipun demikian, Calvin tidak serta merta langsung menghancurkan semua jenis patung, karena pada kehidupannya justru patungpatung dan segala iconography yang tidak berkaiatan dengan keagamaan Calvin tetap gunakan dan ditaruh di rumahnya sebagai karya seni.

\section{Kesimpulan}

Penelusuran diakronis berkaitan dengan sejarah iconography dalam kekristenan dan implementasi Keluaran 20:3(4)-6 sengaja diberikan cukup panjang untuk dapat mengetahui bagaimana persoalan ini telah menghadirkan cukup banyak polemik dan tafsir terhadap isu ini. Tidak mudah untuk memberikan kesimpulan yang valid mengenai tafsir terhadap perintah kedua ini, namun dengan mengamati dari sejarah yang telah dipaparkan bahwa kebanyakan penafsir dan juga gereja mula-mula telah memaknai bagian ini dengan pengertian bahwa perintah hukum yang kedua ini adalah perintah yang penting untuk dilaksanakan oleh orang yang percaya kepada Allah. Dalam sejarah gereja mula-mula terlihat bahwa penggunaan patung dan segala macam bentuk iconography merupakan salah satu bentuk manifestasi dari tindakan penyembahan berhala yang merupakan perlawanan terhadap Allah yang benar.

\section{Referensi}

Adiprasetya. Joas, Makalah Ikonografi Protestan Diskusi Panel Ikonografi di LAI, Jakarta, 24 April 2014

Baker, David L. dkk., Pengantar Bahasa Ibrani. Jakarta: BPK Gunung Mulia, 2004 Barr, James, The Semantics of Biblical Language. Oxford: Oxford University Press, 1961 
Calvin, John. Calvin's Commentaries, vol. 2, The Last Four Books Of Moses Arranged in the Form of a Harmony, trans. Charles William Bingham. Grand Rapids: Baker Books, 2005

Cheung, A. T. Idol Food in Corinth: Jewish Background and Pauline Legacy (JSNTSup, 1999) 39-81

Childs, Exodus: A Commentary. London: SCM, 1974

D. Newton, Deity and Diet: The Dilemma of Sacrificial Food in Corinth (JSNTSup 169: Sheffield; SAP, 1998)

Dyrness, William A. Reformed Theology and Visual Culture. Cambridge: Cambridge University Press, 2004

E.g. Hyatt, Commentary on Exodus. London: Oliphants, 1971

Fee, Gordon D. dan Stuart Douglas, Hermeneutik: Bagaimana Menafsirkan Firman Tuhan dengan Tepat! Malang: Gandum Mas, 2006

Genevieve Young, "Byzantine Iconoclasm: An Imperial Religious Policy Aimed at Unification?" dalam Phronema 23 (2008).

Haris, et al, Theological Wordbook of the Old Testament Vol. 1, 41.

Hayward, "Observations on Idols in Septuagint Pentateuch," in Idolatry. ed. Barton; London: T\&T Clark, 2007

Journal of Theological Studies, NS, 53.1 (2002)

Levenson, Jon D. Sinai and Zion: An Entry into the Jewish Bible. San Francisco: HarperCollins, 1985

Luther, Martin. Luther's Works, vol. 51, Sermons I, ed. and trans. John Doberstein. Philadelphia: Muhlenberg Press, 1959

Martin Luther, Karlstadt's Battle with Luther: Documents in a Liberal-Radical Debate, ed. Ronald J. Sider. Philadelphia: Fortress Press, 1978

Marshall, I. H Marshall, 1 and 2 Thessalonians. NCBC; London: Marshall \& Morgan Scott, 1983

McGrath, Alister E. A Life of John Calvin. Oxford: Blackwell Publishers Ltd, 1995

Miller, Patrick D. \& Hanson, Paul D., and McBride, S. Dean, eds., Ancient Israelite Religion: Essays in Honor of Frank Moore Cross. Philadelphia: Fortress, 1987

Noth, Martin. Exodus: A Commentary. Translated from the German 1959 by John S. Bowden; Old Testament Library; Philadelphia: Westminster, 1962

Osborne, Grant R. The Hermeneutical Spiral: A Comprehensive Introduction to Biblical Interpretation. Revised and Expanded Edition; Downers Grove, Illinois: IVP Academic, 2006

Ryken, Philip Graham. Exodus: Saved for God's Glory. Wheaton, Illinois: Crossway Books, 2005

Sarna, Nahum. Exploring Exodus. New York: Shocken, 1986

Silva, Biblical Words and their Meaning: An Introduction to Lexical Semantics. Grand Rapids: Zondervan, 1983

TDOT 12:33.

von Rad, Old Testament Theology. trans. Stalker; 2 vols.; vol. 1; Edinburgh: Oliver and Boyd, 1962 